\title{
The Strategies of Mineral and Chemical Companies in Terms of the Modern Global Market
}

\author{
Igor B. Sergeev* and Tatiana V. Ponomarenko \\ National University of Mineral Resources "Mining" \\ 21 lines, 2, St. Petersburg, 199106, Russia
}

Received 14.11.2014, received in revised form 20.01.2015, accepted 02.02.2015

\begin{abstract}
The development of economy in terms of globalization, intensification of competition on the world mineral commodity market, reduction in quality of resource base, growth of innovative industries and technologies provide changes in corporate strategies of the global mineral and chemical companies based on the new strategic competitive advantages. The dynamic of the traditional markets and emerging of new industrial markets and innovative facilities of complex balanced usage of the mineral resources to combine their resources effectively, to develop new business models to implement new strategies.

The research objective is to forecast export strategies of the head phosphate producers according with globalization of the phosphate market.

Methods. Integration factors and expected changes in external environment were estimated. All data related to the consolidation and acquisition of companies in mineral and chemical industry for 5 years was picked up and analyzed. The statistical analysis of demand factors was made. A review of the rare-earth elements was carried out.

Key results of the research: new integrative factors and operating regularities of the mineral resources markets were found out, the complex use of the system, scenery, situational and monetary approaches to management was put forward, the global growth-stimulating factors were found out and a forecast of the global phosphate market's development for three main segments was made, the capabilities of complex use of mineral raw material were found out based on the generalized conditions and factors of manufacturing new and traditional types of product of mineral and chemical companies.
\end{abstract}

Keywords: global market, business competition, mineral and chemical company, rare-earth metals, phosphate fertilizers.

Research area: economics.

\section{Introduction}

According to intensification of business competition on the global resources markets, degradation of business environment, decrease of the investment activity and high-profitable giant fields depletion international majors in mineral resources industry develop new competitive advantages so that to sustain effective operations on global market.

The new global challenge facing the world community is to solve food problem and provide economic growth and in presence of the finiteness of land resources it requires planned and balanced gain in agricultural production

(c) Siberian Federal University. All rights reserved

* Corresponding author E-mail address: miner-spb@yandex.ru 
output by increasing yield capacity. The mineral fertilizers (principally nitrogen $(\mathrm{N})$, phosphor $(\mathrm{P})$ and kalium $(\mathrm{K}))$ play key role in this process. $24 \%$ of the world demand capacity for mineral fertilizer sis accounted for by phosphor. That is the reason why the major volume of the phosphate raw materials extraction provides the production of mineral fertilizers. The global market of phosphate fertilizers is notable for demand prevalence over an offer caused by the finiteness of the global phosphate-resources base.

The technological business integration is a clear trend in this sector. The formation of the integrated corporate structures ensures an active role in global economy for both mature and emerging economies. The integration process provides company with competitive advantages but restricts the alternative capabilities for its business. For this reason this process can be described as complex process. Modern mineral commodity markets are the oligopolies where the degree of participant's freedom and mode of entry are predicated upon the market's structure. The high level of concentration and prevalence of large diversified, integrated and network structures are common to companies operating at the mineral resources markets. The estimation of integrative processes' motives and effectiveness is distinct in variety. The neoclassic approach of economics colligates integration not only with increase of the effectiveness but also with possibilities to gain monopolistic advantages and technological factor of production. The exponents of the institutional approach of economics inquire into integration process in terms of transaction costs, agency relationship and property's influence. The dynamic competitive advantages economics approach considered the integration in a context of innovations and adaptation to the lifecycles of products and technologies.

According to the neoclassic approach of economics the main goals of integration are market power's strengthening (Chamberlin, Robinson); technological benefits generated by the union of the successive manufacturing process's stages; reduction of risk and uncertainty (North 1990); slackening of tax and price control. That's why effectiveness of integration will depend on degree of production factor's intersubstitutability; the circumstances of competition and market structure (Bain, Clark). The «structure-behavior-performance» reflects interaction of market structure, company's behavior and strategy's effectiveness (Pakhomova, 2009).

The main disadvantage of the neoclassic approach of economics is that a company is considered to be based on absolute cooperation. And this problem gave rise to development of the institutional economics conceptions. According to the institutional approach a company is considered as a complex of long-term contracts that emphasizes cooperation of economic subjects.

Main advantages of integration are the high level of adaptivity and steadiness against the background of uncertainty as well as contract's protection. O. Williamson (1985) put forward innovative rendering of strategic relationships based on interdependence of participants and long-term contracts. Reduction of transaction costs and its internationalization inside company are considered to be as integrative factors as well as rundown of a contingency of property priorities which have negative outer effects and solution of external problems and problem of assets' peculiarity. The founders of institutional approach of economics considered integrated company as coalition of resources' owners on the one hand (Cheung, 1983) and as cluster of interdependent assets on the other (Alchain, 1972).

The stakeholder theory framed renovated representation of an integrated company as 
"a company mobilizes its resources towards producing a wealth and other profits (exclusion of purposeful wealth destruction, prejudice and intensification of risk) for numerous concerned parties" (Post, 2002). A company's integration is aimed at long-term development performed to reconcile the interests of concerned parties due to system approach to economic, social and ecological business management. We consider the priority of the stakeholders' interests which causes the resources mobilization as well as its effectiveness to be right.

The dynamic competitive advantages are related to the rivalry of old methods with new innovative ones. I.Kirzner (2001), G. Hamel, K. Prahalad (2002) substantiated this approach in their works. This approach conform the development of modern innovative economy in the most comparable way. The dynamic facilities are the organizational operations and tools by means of the management operate the resources base and company's potential towards strategy formation (Grant, 2003, 2011; Teece, 2003). New sources of competitive advantages can be created by the instrumentality of working out new products, concluding the strategic alliances between companies, other organizational innovations generating incremental benefits.

There are three most popular key forms of integration. The horizontal integration often is the extent of competitive and antimonopoly legal system. That is the reason why it is not widely occurring. Diversification and conglomerate integration deceive the effects to be expected so these alliances are fragile. Integration processes historically are connected with the technological business integration.

As advantages of the technological integration can be mentioned the decrease of costs of production including transactional costs, reduction of indirect taxation of intermediate products, ability to implement capital-intensive projects, high resistance to negative market environment's fluctuations.

As for technological integration disadvantages, there are large percentage of direct investment in one particular industry corporation, increase of business risk during industry stagnation, company's overdependence on its departments, necessity of balanced producing process according to stages of operating cycle, decrease of company flexibility, possibility for monopolistic control.

The researches held in Saint Petersburg Mining University found out the main problems of integrative companies' cooperation (Sergeyev, 2012; Ponomarenko, 2011):

- absence of the consistent terminology and approaches to the legal and economic control the integrated structures as well as absence of the standard integrated companies' classification;

- variety of concepts and arguments of integration;

- insufficient justification of estimation proposal of competitive advantages and rational level of integration;

- insufficient development of the estimation methods of corporate integration effectiveness;

- companies' strategic behavior changes influenced by new factors and necessity of mining companies' strategic elaboration;

- absence of the universal business models providing high performance efficiency.

Changing tendencies of the global mineral resources markets are due to the determining influence of such factors as: markets globalization, decrease of economic environment, intensification of business competition, development of innovative processes and decrease of investment activity.

The research objective is to forecast export strategies of the head phosphate producers 
according to the variety of approaches to the strategic behavior's models choice with account of degradation of business environment, globalization of the phosphate market, intensification of business competition and decrease of the investment activity.

\section{Methods.}

It was gathered and summarized the data from the mineral and chemical companies' corporate reports for 5 years. Integration factors and expected changes in external environment were estimated. All data related to the consolidation and acquisition of companies in mineral and chemical industry for 5 years was picked up and analyzed. It was worked out complex approach due to system, scenery, situational and monetary approaches to management of the mineral and chemical companies. The statistical analysis of demand factors for the mineral and chemical production, ethanol's production. A review of the rare-earth elements was carried out.

Analysis of the theory of the integration cooperation and sectorial markets, analysis of the models of the strategic behavior, strategic analysis of the global phosphate market, forecasting methods, methodology of the system approach and situational analysis were made.

\section{Discussion}

New integrative factors

and operating regularities

of the mineral resources markets

There are a lot of special aspects of integration in mining industry such as strengthening of innovative productive potential based on the use of integrated technologies, additional facilities of more complete resources extraction and production of new products with higher level of added value and reduction of risks due to operating in different markets.
Recently incorporation has been the distinctive feature of high consolidated global market of mineral fertilizers (Eurochem, Phosagro, Potash). As an example, Mosaic company is the result of business merger of Cargill Crop Nutrition and IMC Global companies. A lot of global companies were interested in buying Potash Corp., one of the largest global producers of mineral fertilizers, such as BHP Billiton Company, Chinese Sinochem Group Company, Brazilian Vale SA Company and OJSC PhosAgro Company. The K+S Group took over Potash One young company. OJSC EuroChem Mineral and Chemical Company took a position of The $\mathrm{K}+\mathrm{S}$ Group and Belgian part of The BASF and Severneft-Urengoy in 2010 and 2011 respectively. OJSC PhosAgro Company took a position of Metachym and Pikalevo's sodium Company as well as initiated merger of OJSC Cherepovets' Nitrogen and OJSC Ammophos companies. The consolidation of Metachem company's assets was completed. The Potash Corp planned to increase ownership interests in Israel Chemicals Limited from $14 \%$ to $25 \%$. Apache Company bought $49 \%$ of Burrup in 2012 while Yara International Company's ownership interests increased to $51 \%$.

Despite the certain degree of monopolization it is possible to set up two separate competitive groups:

- global markets' participants generally MNEs having vast sales networks and operating at the majority of the key markets;

- local markets' participants generally operating at one geographically local market and operating under cover of government protectionist measures.

There are the most powerful companies operating at the global mineral phosphate fertilizers market such as The Mosaic (USA), The 
OCP (Morocco), The Ma'aden (Saudi Arabia), The Yara (Norway) and The PhosAgro (Russia). These companies influence a lot the aggregate offer and framing the rules of the global mineral phosphate fertilizers market.

But there are some local competitors such as The Eurochem, The Uralchem, The PhosAgro, The Akron, JSC Minudobreniya as for Russia. As for Baltic countries there are The Eurochem, The ARVI, The NPK which are aimed to demand of the particular consumers.

\section{The development of the business models}

of the management companies

The management model selection for company depends on conditions and development of the internal and external company's environment. I.Ansoff (2000) worked out and classified strategic company's behavior models. The selection of the model is due to the expected characteristics of the external environment and the capacity to manage the strategic changes in company. The increasing of interconnection of such external environment's factors as complexity, flexibility and uncertainty proclaims its fast growing changes.

The models suggested by I.Ansoff: reactive model, special management model, long-term planning, strategic planning, strategic management. But these models do not correspond fully to the current and forecast changes of external environment. For this reason it was worked out the complex approach combining system, scenario, situational and cost-based management approaches (Table 1).

As a subject to management the company is regarded as ataggregate of interrelated elements having the external environment and internal structure. The scenario approach admits remodeling the strategic behavior of firms in a changing environment. The situational approach based on establishing links between the type of situation and management principles allows considering the specifics of the strategic assets of the mining company. The cost-based approach provides achieving the management objectives aimed at increasing the company's value through

Table 1. The optimal conditions for the application of management models

\begin{tabular}{|c|c|c|c|c|}
\hline \multirow{2}{*}{$\begin{array}{l}\text { Management } \\
\text { Model }\end{array}$} & \multicolumn{3}{|c|}{ External environment } & \multirow{2}{*}{$\begin{array}{c}\text { Internal } \\
\text { environment }\end{array}$} \\
\hline & Rate of changes & Changes & $\begin{array}{l}\text { Periodicity of } \\
\text { changes }\end{array}$ & \\
\hline Reactive & $\begin{array}{l}\text { Slower than } \\
\text { company's reaction }\end{array}$ & Recurring & Infrequent & $\begin{array}{l}\text { Traditionally } \\
\text { strengths }\end{array}$ \\
\hline Special & $\begin{array}{l}\text { Corresponds to } \\
\text { company's reaction }\end{array}$ & Logically gradual & Infrequent & $\begin{array}{l}\text { Gradual evolution of } \\
\text { abilities }\end{array}$ \\
\hline Long-term planning & $\begin{array}{l}\text { Faster than } \\
\text { company's reaction }\end{array}$ & Logically gradual & Infrequent & New abilities \\
\hline Strategic planning & $\begin{array}{l}\text { Faster than } \\
\text { company's reaction }\end{array}$ & New & Frequent & New abilities \\
\hline $\begin{array}{l}\text { Strategic } \\
\text { management }\end{array}$ & $\begin{array}{l}\text { Faster than } \\
\text { company's reaction }\end{array}$ & New & Very frequent & Dynamic abilities \\
\hline Complex approach & $\begin{array}{l}\text { High level } \\
\text { of factors' } \\
\text { interdependence, } \\
\text { complexity, } \\
\text { flexibility. }\end{array}$ & $\begin{array}{l}\text { Non-linear, } \\
\text { paradigmatic }\end{array}$ & $\begin{array}{l}\text { Very frequent, } \\
\text { unpredictable }\end{array}$ & $\begin{array}{l}\text { Dynamic abilities } \\
\text { and Strategic assets }\end{array}$ \\
\hline
\end{tabular}


the implementation of corporate strategy development.

\section{The global growth-stimulating factors and a forecast of the global phosphate market's development}

Expected changes in the demand for minerals are due to the influence of macroeconomic factors and include three options: pessimistic, most likely, optimistic. Changes in market structure and companies' market power force associated with the processes of integration and disintegration. Forecasted changes in the institutional environment can be quite diverse and include changes in taxation (eg. customs duties), access to mineral resources (auctions), the investment policy's mechanisms (government support and funding, public-private partnerships), globalization (the influence of the WTO), etc.

The global market of phosphate fertilizers is notable for prevalence of demand over supply. Number of regions with deposits of phosphate raw materials is limited, so the market of phosphate fertilizers is highly consolidated. The main suppliers of raw phosphates and phosphate fertilizers are the countries with the resource base: Morocco, the U.S., China, Tunisia, Russia, Saudi Arabia. $90 \%$ of the market is accounted for ten largest producing countries.

Despite the seasonal nature of fertilizer usage, the demand for it is relatively constant. The demand for phosphorus fertilizers, unlike the demand for other types of fertilizers, more stable as phosphorus fertilizers are introduced more often than potassium and nitrogen. The main demand is formed by developing countries in Asia (China, India), Latin America and the Middle East, which accounts for $57 \%$ of global consumption of phosphate fertilizers.

The main consumers of phosphates remain industry of mineral fertilizers and feed phosphates producing. Demand in these sectors will continue to grow rapidly, consistently and universally. This increase is due to the following global factors:

Population growth in the world. According to the United Nations (United Nations) world population will grow at an average annual growth rate of $0.84 \%$. In developing countries, the average annual growth rates of up to $1 \%$. This determines the steady increase in demand for food.

Growth in per head income. According to the International Monetary Fund (Monetary Fund) the average annual GDP growth rate over the next five years is $4.5 \%$. Developing countries will be a locomotive of the world economy where the average annual GDP growth of about $6 \%$ is predicted. Growth of people's welfare leads to structural changes in the diet - preference is given to protein foods, meat and poultry. In turn, this leads to an increase in demand for feed phosphates and fertilizers.

Reducing the amount of land suitable for agriculturalpurposes. Thepossibility of expanding arable land is practically exhausted. Area of agricultural land per head for 20 years decreased by 1.5 times. This causes the intensification of agriculture, especially in developing countries with rapidly growing population.

Increased production of biofuels. Due to the increase in global demand arable lands are increasingly used for growing crops as a raw material for the production of biofuels. According to forecasts of the OECD -FAO, the average growth rate over 5 years will be more than $10 \%$ (Phosagro).

Thus, demand for phosphorus production is expected to increase in the coming years. While the demand is expanding everywhere, only a few countries have resource base. This fact leads to significant market monopolization. Among developing countries generating major demand for phosphates only China has its own raw material base. However, despite the increase in 
the production capacity in the next decade China will not be able to meet its needs for high-quality raw materials on its own.

At the same time the instability of phosphates' supply in the world market gives rise to concern. First, it is due to the gradual depletion of ore at existing fields such as deposits in Florida, USA. Secondly, a number of suppliers of phosphates have the export's restriction policy due to the rising of domestic demand for phosphorus-containing products. Thirdly, concerning is unstable geopolitical situation in the Arab countries that are the major producers of phosphate raw materials.

Discrepancy of growing demand and fluctuated global supply of phosphates encourages the maintenance of high prices for phosphates. Currently the deposits with high phosphorus content and low content of harmful impurities are uncommon. Therefore, the poorer deposits are developing increasingly that leads to costs increasing for raw materials.

High prices for the phosphorus production especially for fertilizers and a tendency for its further growth exacerbate one of the most actual problems of the modern world economy - the problem of hunger in developing countries. While the producers of fertilizers claim its strategic goal of increasing productivity and food security population, high fertilizer prices make it virtually inaccessible to some of the poorest farmers in Africa, Asia and Latin America.

In the near future the growth in demand for phosphates is forecasted for all consumer groups: fertilizers, feed phosphates, technical and food phosphates. Moreover, the competition between these consumers will also gradually increase. This is due to the fact that demand for phosphorus products is formed not only by traditional consumers such as agriculture, building materials industry, food industry, household chemicals. According to the scientific and technological development of various industries the new phosphorus consumers appear. For example manufacturers of lithium-phosphate accumulators that are installed on modern hybrid and electric cars.

Common feature for manufacturers of phosphorus-containing products is a pretty deep processing of raw materials and production of goods with high added value. About a half of the concentrate produced is usually used within the country of manufacture for further production of phosphoric acid and fertilizers. Only a few companies supply their concentrates for export. The situation is similar to the implementation of the phosphoric acid produced. Therefore, the list of the main producing countries of phosphate raw materials is different from the list of the largest exporting countries.

The largest producer of phosphate raw materials - China - does not supply products for export virtually at all. It is connected with the state strategy restricting exports of phosphoruscontaining products due to high prices for phosphate and increasingly growing domestic needs. Since 2012 the government set up $82 \%$ export duty for the phosphorus products. As a result of this policy, despite the increase in the production of phosphate raw materials, the export of phosphate fertilizer from China declined by more than $40 \%$. Thus, the global market of phosphate raw materials is represented by only a few companies. The largest suppliers are OCP (Morocco), Mosaic (USA) and PhosAgro (Russia).

The leading country exporting phosphate concentrates (about 13.5 million tons per year) is Morocco. This is caused by the possession of the world's largest resource base, relatively low costs of production, transportation and sales. The stateowned company OCP is a major exporter which has a wide distribution network. The main export markets for Moroccan phosphate concentrates 
are India, the United States, Western European countries. The OCP export strategy focused on building up a sales share of more concentrated and expensive products. For these purposes, major investments are injected in the modernization of existing production facilities and building new ones. In addition, the OCP plans to increase production of phosphate raw materials from 28 to 55 million tons. Thus, with its huge reserves of raw materials and continuing to implement its strategy of deeper processing and export of products with high added value, Morocco in the foreseeable future will retain its leading position in the global phosphate industry while the OCP will strengthen its influence on world market conditions.

In recent years the global market of phosphate raw materials has its new trend: with growth of domestic demand the largest producing countries become net importers such as China and the United States. The governments of these countries are actively pursuing a policy to reduce the dependence of the national economy on imports of phosphorus-containing products.

In general, the export strategies of world producers of phosphate raw materials are aimed at the production and export of products with high added value, especially fertilizers. This is evidenced by a number of examples when corporations are operating the absorption of high-tech manufacturing units or invest in the construction of new factories for the production of fertilizers. Among such companies can be mentioned OCP (Morocco), Yara (Norway), OCI (Egypt), PhosAgro (Russia) and Ma'aden project in Saudi Arabia.

Also the expansion of markets is purposed in the export strategies of world manufacturers of phosphorus-containing products. Due to the seasonality of fertilizer usage, the specifics of soil in different countries, changes in demand and prices for grain and other factors the demand on phosphorus-containing products is subject to fluctuation. Therefore, one of the main tasks for suppliers is to predict the change of demand geography and quantity demanded for products in the short term as well as to conclude an export contracts.

India being the world's largest consumer of phosphate fertilizers in recent years has purchased mainly nitrogen fertilizer due to rising prices for potash and phosphate. As a result, by the end of 2012 India had recorded imbalance essential elements (phosphorus, potassium and nitrogen) in the soil that caused lower yields and quality of agricultural products. Therefore, in 2013-2014forecasted recovery of phosphate fertilizer consumption accounts to $7 \%$ from the level of consumption in 2012 that is equal to 500 tons of P2O5 (IFA).

According to forecasts of IFA (International Fertilizer Industry Association) and analytical agency Fertecon in the upcoming season 2013-2014 with the growth of world fertilizer consumption by $2.4 \%$ outpacing growth demand for phosphorus fertilizers by $3.5 \%$ is expected. At the same time the main demand will be formed by high-growth markets in Africa, Central Asia and Latin America. Thus we can expect that the export strategy of phosphates manufacturing companies in the short term in 2013-2014will focus on expanding its operating in these markets.

\section{The capabilities of complex use of mineral raw material \\ for manufacturing new products \\ of mineral and chemical companies}

The global market of phosphoruscontaining products is highly organized market. Despite the inherent features of a monopoly it has created an environment of fierce competition. In terms of the phosphate market monopolists are countries provided with the raw material base. However, due to the rapid growth of phosphorus- 
containing products consumption, the gradual depletion of deposits, the strengthening process of economic globalization the global phosphate market competition will be getting more intensive and the existing structure of consumers and suppliers can change dramatically in the near future. Even today exporting countries are affected by commodity prices changes as well as changes of the world market general environment.

The high growth of global industry, rapid growth of the world population, limited and exhaustible natural mineral resources stimulate the complex use of extracted raw materials. Phosphorus-containing product manufacturers build their long-term development strategy based on the diversification of production in order to reduce the negative impact of such factors as depending on price fluctuations, increased competitiveness. For commodity companies such opportunities lie in the complex processing of mineral raw materials as well as in increasing the degree of extraction of useful components, use a variety of raw materials, the development of supply chain and infrastructure and further integration.

Diversification of production in the mining industry is characterized by the following features:

1) single mineral resources base is developing;

2) total production capacity of the company is used;

3) single technology is used, there is sufficient flexibility in the technological capabilities to produce products;

4) level of complexity, disposability and the rational use of mineral resources is increasing;

5) cost of production, processing and marketing is reduced;

6) more jobs are created as well as the development of human capital is stimulating;
7) available channels of distribution are used;

8) area of disturbed land designated for the storage of waste production and reduced air pollution are reduced;

9) risks associated with the cyclical nature of demand for certain products and market environment are reduced.

A special kind of product diversification in mining is the complete use of mineral raw materials (CUMRM). Rational use of natural resources is achieved by simultaneously or sequentially extracting the valuable components from the raw material as well as using some of the valuable properties of materials. CUMRM projects are characterized by a number of technological and economic characteristics that define its competitive advantages (Table 2).

Quality of raw phosphates and phosphorus waste production allows not only the phosphoric acid production but also fundamentally new products and compete at new markets.

Due to the high level of technological development the European Union and the United States generate the greatest demand for metals that gradually build up its deficit. Saying scarce metals is understood economically significant mineral resources which are exposed to the termination of supplies. Risk of interruption of scarce metals supplies on the world market is due to the several reasons. Firstly, the major part of scarce metals resources is concentrated in a few countries in Africa and Asia which are notable for political and economic instability. Secondly, scarce metals are often found in complex raw materials and can be produced as associated components by a technologically complex and costly processes.

In EU countries studies were conducted to determine the 14 scarce metals which include platinum group metals (PGM) and the rare earth metals (REM).There are five metals particularly 
Table 2. Comparative analysis of product diversification projects and CUMRM

\begin{tabular}{|l|l|l|}
\hline \multicolumn{1}{|c|}{ Project special aspects } & \multicolumn{1}{|c|}{ Product diversification } & \multicolumn{1}{c|}{ CUMRM } \\
\hline 1. Quality of produced products & $\begin{array}{l}\text { All types of commercial products } \\
\text { are full }\end{array}$ & Produced both full and by-products \\
\hline $\begin{array}{l}\text { 2. Relationship between } \\
\text { technological processes and stages }\end{array}$ & Presence or absence & $\begin{array}{l}\text { Communication necessarily } \\
\text { presents }\end{array}$ \\
\hline 3. Usage minerals & One or more kinds & One kind \\
\hline 4. Influencing factors & $\begin{array}{l}\text { Demand, competition, the yield of } \\
\text { products, innovation, etc }\end{array}$ & $\begin{array}{l}\text { Demand, competition, the } \\
\text { profitability of products , } \\
\text { innovation, government } \\
\text { regulation, etc. }\end{array}$ \\
\hline 5. The aim of the project & Profitmaximization & $\begin{array}{l}\text { Rational and comprehensive } \\
\text { utilization of mineral resources }\end{array}$ \\
\hline 6. Type of investment project & Independent and complementary & Complementary \\
\hline $\begin{array}{l}\text { 7. Management and control } \\
\text { methods of the project }\end{array}$ & $\begin{array}{l}\text { Corporate control, economic } \\
\text { methods }\end{array}$ & $\begin{array}{l}\text { State control, direct and indirect } \\
\text { (economic methods) }\end{array}$ \\
\hline $\begin{array}{l}\text { 8. The main types of risks } \\
\text { 9. Type of cashflow }\end{array}$ & Eliminationofdiversifiedrisk & $\begin{array}{l}\text { Saving diversified and non- } \\
\text { diversified risk }\end{array}$ \\
\hline $\begin{array}{l}\text { 10. The procedure for determining } \\
\text { the discount rate }\end{array}$ & $\begin{array}{l}\text { Individual discount rate by type of } \\
\text { commodity products }\end{array}$ & Single discount rate \\
\hline
\end{tabular}

Table 3. Scarce metals, the most critical for the EU economy

\begin{tabular}{|c|c|c|c|c|c|}
\hline \multirow[b]{2}{*}{ Metal } & \multicolumn{2}{|c|}{ Market factors } & \multicolumn{2}{|c|}{ Political factors } & \multirow[b]{2}{*}{ Total risk } \\
\hline & $\begin{array}{l}\text { Chance of rapid } \\
\text { demand growth }\end{array}$ & $\begin{array}{l}\text { Restrictions on } \\
\text { expansion of } \\
\text { production }\end{array}$ & $\begin{array}{c}\text { Offer's } \\
\text { concentration }\end{array}$ & Political risks & \\
\hline $\begin{array}{l}\text { Dysprosium } \\
\text { (REM) }\end{array}$ & High & High & High & High & \multirow{5}{*}{ High } \\
\hline $\begin{array}{l}\text { Neodymium } \\
\text { (REM) }\end{array}$ & High & Medium & High & High & \\
\hline Telluride & High & High & Low & Medium & \\
\hline Gallium & High & Medium & Medium & Medium & \\
\hline Indium & Medium & High & Medium & Medium & \\
\hline
\end{tabular}

the lack of which is critical for energy and energysaving technologies among them (Table 3).

These elements have unique properties ensuring its usage in the field of high technologies such as biotechnology, nuclear energy, energy generation from renewable sources, space technology, etc. In recent decades, the demand for rare earth metals has steadily increased and the volume of the market for the past 50 years increased from 5 to 125 tons per year. This is due to the use of REM in emerging industries related to the production of hybrid cars, defense equipment, computer and television technology, lasers, superconductors and other high-tech products.

According to estimates of the Australian company Lynas, global demand for rare earth metals will have increased by $40 \%$ by 2014 
compared to 2010 (Levin, 2011). The main demand for REM is generated by technologically developed countries: China (54\%), Japan and South Korea (24\%), EU (13\%) and the USA (8\%). The supply of rare earth metals on the world market is limited to $97 \%$ of the market for supplies from China. Thanks to its raw material base, low environmental standards and cheap labor China for over 15 years had been supplying the REM on the world market at dumping prices that led to unprofitable production REM outside China.

Sales volumes and prices in the market fluctuate significantly and actually are determined by China. Many countries faced a serious problem of supply national economies with rare earth metals. In consuming countries such as the U.S. and Australia emergency measures have been adopted to promote scientific and technological basis for REM extraction. According to this fact China's share in the global market of REM should be reduced twice by 2020 . Alternative source of scarce metals is phosphorus ore while potential producers REM - mineral and chemical companies.

\section{Conclusions}

1. It was identified the new factors of integration for the mineral and chemical markets including the development of innovative processes, the use of integrated technologies, the possibility of more complete extraction of mineral resources and production of new products with high added value, reducing market risks. It was found that integration processes are influenced by these factors.

2. It was found that the rate of change of the external environment in modern conditions related to the interrelationship of factors, their complexity, mobility and uncertainty is updating revision of companies' strategic behavior models. It was proposed the complex application of system, scenario and situational approaches to the management of mineral and chemical companies.

3. It was identified global demand and growth factors and predicted the development of the global market for phosphates in three segments. Increase in the demand for phosphate raw materials, primarily in the developing countries of Asia and Latin America is forecasting. This is due to the increased demand for fertilizers, biofuels and the development of new technologies.

4. It was summarized the production conditions and factors of traditional and new types of products in the mineral and chemical companies. Based on it opportunities comprehensive utilization of mineral resources were identified. The strategic objective of creating new long-term competitive advantage of the mineral and chemical companies in the global market is possible be means of the diversification of production and range of exported products. Innovative potential of the mineral and chemical sector, increasing the depth of processing and comprehensive utilization of mineral raw materials are aimed at ensuring the growing demand of high-tech industries.

The results obtained clarify the strategic management, competition and integration theories with respect to mineral commodity markets, in particular mineral and chemical. The obtained results make it possible to predict the development of traditional and new markets as well as refine and adjust the strategy of mining companies with the influence of specific factors.

\section{References}

1. Alchian, A., Demsetz, H. (1972). Production, Information Costs, and Economic Organization. American Economic Review, 62, 777-795. 
2. Ansoff, I. New corporate strategy. SPb: St. Petersburg. 2000, $416 \mathrm{p}$.

3. Cheung, S. (1983). The Contractual Nature of the Firm. Journal of Law and Economics, 26 (April), 1-21.

4. Grant, R. (2003). Resource concept of competitive advantages: practical conclusions for a strategy formulation. Notes of the St. Petersburg University, Series 8, Management, Vol. 3, 47-75.

5. Grant, R. Modern strategic analysis. Fifth prod. S-Pb: St. Petersburg, 2011. 560 p.

6. Hamel, G., Prahalad, K. Competing for the future. Moscow: Olymp-business, 2002. 246 p.

7. Kirzner, I. Competition and business. Moscow: UNITI-DANA, 2001. 239 p.

8. Levin, B.V. (2011). Markets of rare-earth elements Fundamental long-term change and new opportunities of their industrial receiving from an apatite concentrate. Materials of the international scientific and practical seminar. Moscow: JSC NIUIF. 94-124.

9. North, D. C. Institutions, Institutional Changes and Economic Performance. Cambridge: Cambridge University Press, 1990. 240 p.

10. Pakhomova, N., Richter, K. Economy of the branch markets and politician of the state. Moscow: JSC Economic Publishing House, 2009. 815 p.

11. Ponomarenko, T., Sergeev, I. (2012). Justification of strategic investment decisions in the integrated mining companies on the basis of the stakeholders theory of firm. Mining journal. News of higher education, 7, 23-31.

12. Post J. E., Preston L. E. \& Sachs S. Redefining the Corporation: Stakeholder Management and Organizational Wealth. Stanford, 2002. 376 p.

13. Sergeev, I., Ponomarenko, T. (2011). Development of strategic competitive advantages of mining companies: institutional and theoretical aspects, Problems of modern economy, 4, 104-108.

14. Teece, D. J., Pisano, G., \& Shuen, A. (1997). Dynamic capabilities and strategic management. Strategic Management Journal, 18(7), 509-533.

15. Williamson, O.E. The Economic institutions of capitalism: Firms, markets, relational contracting. New York: Free Press, 1985. 702 p.

16. Eurochem. Annual reports 2010-2013. Available at: http://www.eurochem.ru (accessed 10 January 2013).

17. Phosagro. Annual reports 2010-2013. Available at: http://www.Potash.Corp.com (accessed 10 January 2013).

18. PotashCorp. Annual reports 2010-2013. Available at: http://www.Potash.Corp.com (accessed 10 January 2013).

19. United Nations. Available at: http://www.un.org (accessed 28 April 2013).

20. International Monetary Fund. Available at: http://www.imf.org (accessed 28 April 2013).

21. The World Bank. Available at: http:// www.worldbank.org (accessed 28 April 2013).

22. W. de Heij. Risks and Opportunities in the Global Phosphate Rock Market. Available at: http://www.snb.nl/files (accessed 28 April 2013).

23. A Review of National Resource Strategies and Research. Available at: http://www.defra.gov. uk (accessed 28 April 2013).

24. IFA. Available at: http://www.fertilizer.org (accessed 28 April 2013). 


\title{
Стратегии минерально-химических компаний
}

\section{на современном глобальном рынке}

\author{
И.Б. Сергеев, Т.В. Пономаренко \\ Национальный минерально-сырьевой \\ университет «Горныйџ \\ Россия, 199106, Санкт-Петербург, 21, линия 2
}

Развитие экономики в условиях глобализации, усиление конкуренции на мировых сырьевых рынках, приводящее к его монополизации, снижение качества ресурсной базы, развитие инновационных отраслей и технологий обусловливают изменение корпоративных стратегий мировых минерально-химических компаний на основе новых стратегических конкурентных преимуществ.

Глобальный рынок фосфатных удобрений в настоящее время является рынком продавцуа, что вызвано ограниченностью мировой фосфатно-сырьевой базы. Условия конкуренции на товарных и ресурсных рынках при производстве минеральных удобрений закономерно определяют необходимость укрупнения компаний. Интеграция компаний является качественно новым этапом в системе организационно-экономического взаимодействия, оптимизирует использование производственных ресурсов и структуру бизнеса и направлена на повышение эффективности.

Динамика традиционных рынков минеральных удобрений и появление новых отраслевых рынков, с одной стороны, и инновационные возможности рационального и комплексного использования минерального сырья, с другой, стимулируют компании к эффективному объединению ресурсов, формированию новых бизнес-моделей, реализации новых стратегий. Это позволяет более эффективно и результативно конкурировать на глобальных сырьевых рынках. Поэтому представляет несомненный интерес исследование деятельности компаний на рынках минеральных удобрений и рынках новых продуктов с учетом новых рыночных факторов и конкурентных преимуществ стратегического характера. Цель исследования уточнив подходы к выбору модели стратегического поведения в условиях глобализации фосфатного рынка в условиях ухудшения экономической конъюнктуры, усиления конкуренции и снижения инвестиционной активности, спрогнозировать экспортные стратегии ведущих мировых производителей.

Методика исследования: собрана и обобщена информация из корпоративных отчетов компаний минерально-химического сектора за 5 лет; на основе корпоративных пресс-релизов и анализа инвестиционной активности компаний выполнена оценка факторов интеграции и ожидаемых изменений во внешней среде; собрана и проанализирована информация по сделкам слияний-поглощений минерально-химического сектора за 5 лет (аналитические обзоры и отчетность компаний); разработан комплексный подход с учетом системного, сценарного, ситуационного и стоимостного подходов куправлению минерально-химическими компаниями; выполнен статистический анализ факторов спроса на минерально-химическую продукцию, производства этанола, кормовых фосфатов и построены статистические прогнозные модели; выполнен обзор рынка редкоземельных элементов.

Применяемые методы: анализ теорий интеграционного взаимодействия и отраслевых рынков, анализ моделей стратегического поведения, стратегический анализ мирового фосфатного рынка, методы прогнозирования, методология системного подхода и ситуационного анализа. Основные результаты исследования: 1. Bыявлены новые факторы интеграции и закономерности функиионированияминерально-сырьевыхрынков. 2. Предложенокомплексное применение системного, сценарного, ситуационного и стоимостного подходов к управлению минерально-химическими компаниями. 3. Выявлены глобальные факторы роста спроса и составлен прогноз развития глобального рынка фосфатов по трем сегментам. 4. Обобщены 
условия и факторы производства традиционных и новых видов продукции минеральнохимических компаний, на основе чего выявлены возможности комплексного использования минерального сырья.

Ключевые слова: глобальный рынок, конкуренция, минерально-химическая компания, редкоземельные металль, фосфатные удобрения.

Научная специальность: 08.00.00 - экономические науки. 